Michelson, Emily.

\title{
The Pulpit and the Press in Reformation Italy.
}

Cambridge, MA: Harvard University Press, 2013. Pp. 262. ISBN 978-0-67407297-8 (hardcover) \$39.95.

Emily Michelson's new book brings to light the efforts of men who were "on the front lines of a more desperate war than anything they had ever imagined" as western Christendom splintered-Italian preachers who gave and published sermons in the vernacular (1). As Michelson argues, these preachers, both mendicants and secular clergy ranging from bishops to parish priests, found themselves battling what they believed (often wrongly) was widespread heresy. As the vernacular sermon was the only part of Catholic services most laity would understand, they agonized over what to say and not say in an attempt to prevent apostasy and bring potential heretics back into the fold.

Michelson's excellent volume engages in several of the debates that have recently developed about how historians understand the reform of Catholicism in the early modern period. Through a combination of social, intellectual, and religious histories, and using a variety of sources largely ignored by Anglophone historians (including sermon books, treatises, and pamphlets), she argues for a much more complicated and multivalent picture of reform. Nothing was clear 
cut or easily achieved through top-down reform. The Catholic Church was not strictly the repressive institution of the "Counter-Reformation." It neither cut the laity off from the scriptures entirely nor encouraged ordinary laypeople to study the Bible. Laity as a whole were neither passive recipients of a new, reformed Catholicism nor recalcitrant defenders of the old traditions. Everything about this period for Catholicism required negotiation, alterations based on local realities, and the flexibility of everyone involved, lay and clerical alike. This book thus makes a valuable contribution to a growing number of studies challenging us to reexamine Catholic reform in light of its numerous contradictions and complications.

In five chapters, Michelson examines the contexts in which sermons were relevant and important to both clergy and laity, and how they were structured; she then turns to the works of several preachers famous in their own time (some still famous in ours). Finally, she explores how mendicant preachers adjusted to their new role after the Council of Trent, when the responsibility for preaching to and teaching the laity was laid firmly at the feet of bishops, in essence cutting the mendicants out of the equation. She compares the works of elite Franciscan friars Cornelio Musso and Franceschino Visdomini, who developed dissimilar strategies and ideas about preaching and the transmission of scripture. Next she turns to two bishops, Luigi Lippomano in Verona and Girolamo Seripando in Salerno, who likewise developed very different programs in order to best serve their dioceses. These men had very similar careers, but came to divergent conclusions about preaching and the level of accessibility of scripture appropriate for the laity. Musso believed scripture should remain "mysterious and inaccessible" to the laity (79) while Visdomini argued that his audience was capable of reading scripture with the proper guidance. Lippomano wanted scripture to be taught orally, ideally through a bishop's sermons, so that the message could be controlled. Seripando, personally preaching to his southern diocese, crafted his sermons so that they were based on scripture but did not explicitly teach the texts to the laity, as he felt such direct access was dangerous. Michelson's case studies of these four men, complete with fascinating and sometimes entertaining translations of portions of sermons, clearly demonstrate the varieties of possible reform strategies based on the fears and beliefs of the individual and the realities of his audience and location.

Michelson also examines treatises on preaching, ostensibly written for the laity but in fact more useful for clergy. As Michelson argues, these treatises 
display evident disdain for the semplici et idioti to whom these authors directed their works, which can hardly have been an effective strategy to convince people to remain orthodox. And yet, in both these treatises and the post-Tridentine mendicant sermons she examines in her final chapter, Michelson argues that underneath the contempt for the unlettered laity we can read an acknowledgement of the laity's role in reform. Although most of these preachers had serious misgivings about providing the laity with the scriptures, owing to their belief that improper readings of the Bible were at the root of the Protestant Reformation, for the most part they accepted that they could not cut the laity off from scripture entirely. In this acquiescence to lay desires, albeit in a limited and controlled way, Michelson argues that we can see some recognition by the clergy that reform was a negotiation, not a simple order. Though this is not a new argument about Catholic reform, usually it is the historian who sees a negotiation of which the historical actors sometimes seem unaware. Here instead is an example of preachers struggling with the negotiating process, unwilling to give vernacular Bibles to the laity but unable to limit their sermons to catechetical instruction alone.

This book makes a valuable contribution to scholarship on the early modern Catholic Church across Italy, with helpful comparative information on Catholic preachers and sermons across Europe. It also takes another step towards breaking out of the old historiographical mould that only wants to see the Catholic Church as repressive, monolithic, and, in more triumphant tellings, accomplishing a quick recovery from the Protestant Reformation.

Celeste mcnamara, College of William and Mary 